\title{
Deflation improvements in the UK National Accounts
}

\author{
Steve Drew Office for National Statistics
}

\section{Summary}

As part of wider developments to improve the quality of the UK National Accounts, ONS will introduce two key improvements to the methods by which volume estimates of gross domestic product (GDP) are calculated in the Blue Book 2011 consistent Quarterly National Accounts release, which will be published on 5 October 2011. The first will be the harmonisation of the deflators used across the accounts. The second is replacement of Retail Price Index (RPI) series with Consumer Price Index (CPI) series in forming the deflators.

This article sets out how these changes will affect the components of the UK National Accounts. It also explains how this will bring the UK methods into line with international best practice and improve the coherence of volume measures within the UK National Accounts, as well as assisting international comparability.

\section{Context}

The volume growth of GDP - sometimes referred to as the real growth rate - is one of the most important economic indicators. Changes in current price GDP between any two periods can be caused either by a price change or a change in the volume of economic activity or a combination of the two. For many purposes, it is important to know which. By removing the effect of price change, the volume change can be derived. The process of deflation, which removes the effect of price changes, is used for this purpose. Algebraically:

$$
\text { volume index }=\text { current price index } / \text { price index } \times 100
$$

As previously announced in Everett (2010), ONS has been working on system changes to improve the quality of the National Accounts. The introduction of the new systems will coincide with the move to the revised Standard Industrial Classification (SIC) and Classification of Products by Activity (CPA), the details of which were set out in Hughes et al. (2009).

One of the main focal points of the system re-development has been improving the consistency of methods across each component within National Accounts. A key area of improvement concerns the approach to deflation. The aim has been to ensure that the methodology complies with international best practice and guidance. Currently, this is most fully set out on the Handbook on 
Price and Volume Measures in National Accounts (Eurostat 2001). The Handbook sets out the following desirable properties for deflators:

1. Completeness - in terms of the deflator relating to all of the component to be deflated

2. Valuation - output should be deflated at basic prices and final consumption expenditure at purchasers' prices

3. Quality change - where relevant, changes in quality should be reflected in the volume estimate

4. Conceptual consistency - deflators should be consistent with national accounting concepts

More specifically, the Handbook implies:

- The deflators which are used should be consistent across the range of the national accounts. While this may seem an obvious statement of best practice, as set out below, it has not hitherto been the case for the UK National Accounts

- Where relevant and available, producer price indices constitute ideal deflators for market output

- For both conceptual reasons and to help international comparability, the Harmonised Index of Consumer prices (HICP) should be used wherever possible to deflate consumer spending

The rest of the article sets out how this agenda is being taken forward in the UK National Accounts. Further details of the changes are set out in the Annexes.

\section{A new consistent approach to deflation in the National Accounts}

Hitherto, a range of existing price indices have been used to construct deflators for the components of GDP:

- Consumer prices, currently RPI series

- Producer Prices, which include Producer Prices for goods for the domestic market (PPI), Producer Prices for goods for export (EPI), Producer Prices for goods that are imported (IPI) and Services Producer Prices (SPPI) - there is no separation of domestic output and export in SPPI

- Other deflators which are either from specific sources to deflate specific products (such as agriculture or construction), or more general deflators which are used where specific price indices are not available (such as Average Weekly Earnings (AWE) and the Financial Times Stock Exchange (FTSE) index)

These price indices have been used to construct deflators for the components of the output measure of GDP. Similar price indices have been separately combined to provide deflators for the 
expenditure components of GDP. While efforts have been made to avoid egregious problems, this approach leaves open the possibility of significant inconsistencies between the output and expenditure measures of GDP. This is clearly undesirable.

Accordingly, in future, rather than a piecemeal approach to deflation in different systems, consistency will be established by having a common gateway for deflators through the short-term output based measure of GDP, referred to as GDP(O). In general, the GDP(O) system will hold the source deflators and produce domestic output deflators for the 112 products, which the National Accounts now identify (for reference, these products are set out in Annex D). These series will be used as the basis for the deflators in the majority of other systems, and thus ensure improved consistency between the output and expenditure deflators.

There will be four main exceptions:

- Household Final Consumption Expenditure (HHFCE) will use the CPI price series

- Gross Fixed Capital Formation (GFCF) will also use the IPI to deflate expenditure on imported capital goods and capital services

- Trade in Goods will use the EPI and IPI to deflate exports and imports respectively

- Trade in Services will also use deflators from other sources where the GDP(O) deflators are not appropriate

Diagrammatically, the new approach is set-out in Figure 1.

\section{Figure $1 \quad$ New flow of deflators through the National Accounts}

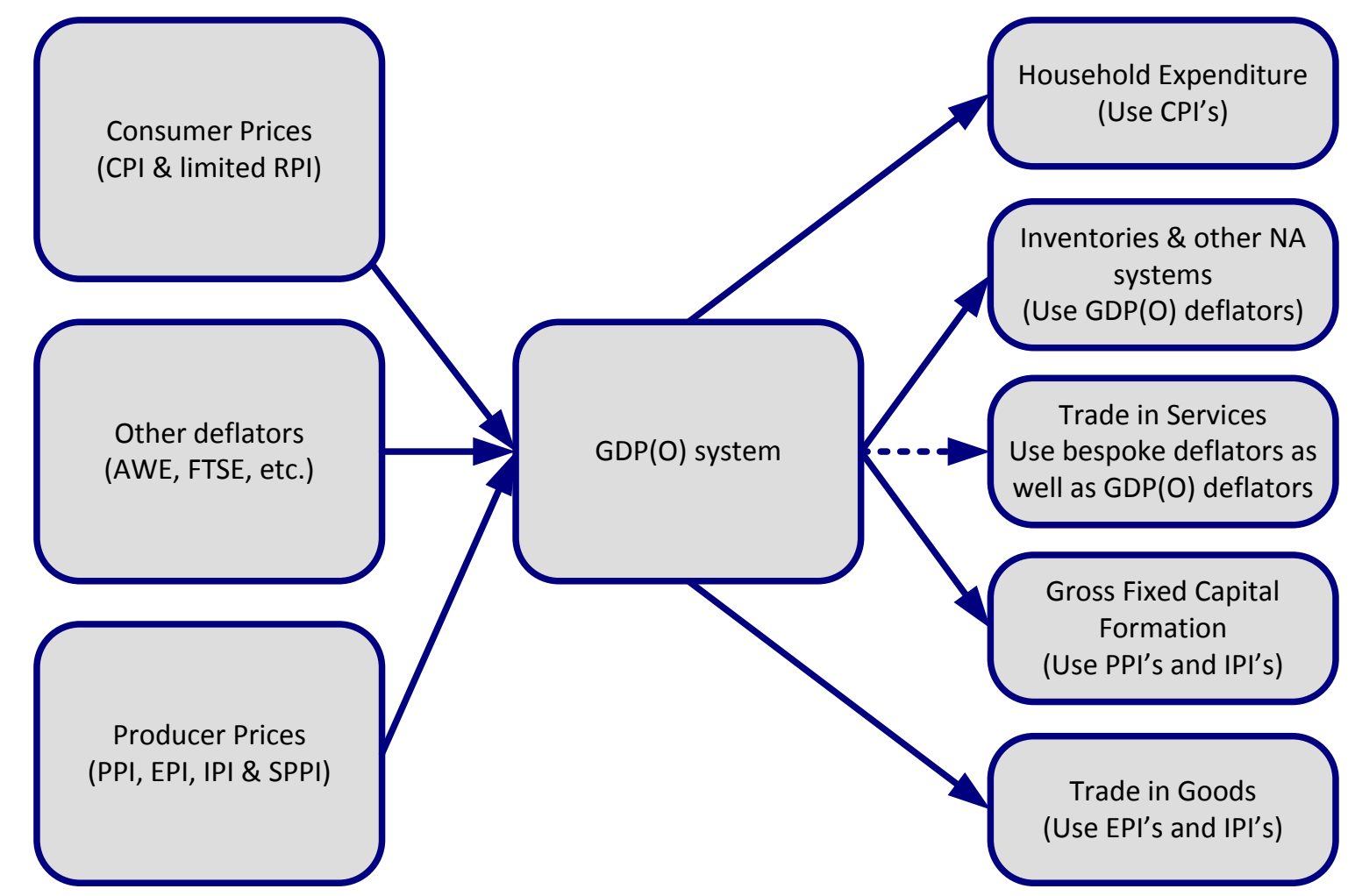

More details of these changes are set out in Annex A. 


\section{Replacement of deflators based on the RPI with ones based on the CPI}

Where goods and services are provided to, and consumed by households, a relevant price index needs to be used to deflate the relevant current price series. As noted above, the RPI has traditionally been used for this purpose, for many years being the only one available. However, CPI has a number of advantages over the RPI for this purpose, as discussed below, and the international guidance is clear that the CPI should be using in preference.

The first advantage concerns coverage. The UK National Accounts relate to the whole economy and all households. Similarly, the CPI is designed to relate to all private and institutional households and foreign visitors to the UK. It is thus well fitted for use in the National Accounts. By contrast (see the Consumer Price Indices Technical Manual (ONS, 2010a)), the RPI relates only to private households. Within those, it excludes ones whose income is within the top four per cent of all households, as well as pensioner households which derive more than three-quarters of their income from state pensions and benefits. The RPI is thus not as well suited for National Accounts needs.

Secondly, the CPI takes its weights from the breakdown of household monetary expenditure component of the National Accounts. By construction, therefore, its weighting structure meets the National Accounts' needs. By comparison, the weights for the RPI are derived from a separate household budget survey, the Living Costs and Food Survey; these weights differ, to a degree, from those in the National Accounts.

Third, the RPI and its methodology are unique to the UK. There is no guarantee of consistency with similar national price indices produced for other countries. By contrast, the CPI is produced according to a harmonised methodology across the EU. Its use is therefore likely to improve international consistency between GDP volume estimates.

Finally, the formula used to compute the CPI is predominantly based on a geometric mean whereas the RPI is computed as an arithmetic mean of price movements. This means that the RPI takes no account of substitution between similar products when one becomes relatively more expensive than others. It is unable to allow for consumers economising on the product becoming relatively dear and purchasing more of those which have become relatively cheap. By contrast, the CPI's formula does allow it to have regard to such substitution. In this sense, the CPI has a more economically rational basis than does the RPI. Annex $\mathrm{C}$ has further discussion of the formula differences.

For all of these reasons, ONS proposes to follow the course set out in the international best practice guidance and move towards deflators based on the CPI. This is also consistent with the course already followed for the calculation of the Retail Sales Index (RSI). The methodology for the RSI was updated in May 2009 (see McLaren, 2009) and its deflation has since then also been based on the $\mathrm{CPI}$, in the light of the same considerations as are set out above.

Annex $B$ to this paper sets out the details of the changes that will be made. 


\section{The impact of the changes}

When the Quarterly National Accounts consistent with Blue Book 2011 is published in early October 2011, a series of articles will be published for the main National Accounts aggregates setting out:

- The identifiable impact of the SIC change

- Effects of changes to methods and data sources

- An analysis of revisions from the previously published datasets

Identifying the effects of the move towards deflators based on the CPI will be an important part of this.

\section{Conclusion}

As previously announced, the UK National Accounts will harmonise the use of deflators across the accounts as well as replacing RPI series with CPI series as deflators. The former change should improve the coherence of volume measures in the UK National Accounts. The latter change also has a number of advantages and aligns UK methods with those in other EU countries, thereby improving the comparability of data.

\section{Acknowledgements}

The author would like to thank Gary Brown, Gareth Clancy, Glenn Everett, Pete Lee, Sanjiv Mahajan, Craig McLaren, Darren Morgan, Jamie Pritchard, Andrew Walton and Rich Wild who provided much of the detail provided within this paper.

\section{Contact information}

steve.drew@ons.gov.uk 01633456119 


\section{References}

European Commission (2010). Commission Regulation 715/2010, OJ L 210, p. 1 11.8.1997 Available at: http://eur-lex.europa.eu/LexUriServ/LexUriServ.do?uri=OJ:L:2010:210:FULL:EN:PDF

Eurostat (2001). Handbook on price and volume measures in National Accounts, Available at: http://epp.eurostat.ec.europa.eu/portal/page/portal/product details/publication?p product code $=\mathrm{K}$ S-41-01-543

Everett G (2010). 'Plans for Blue Book 2010', Economic and Labour Market Review, April 2010, Volume 4, No 4, pp 54-55. Available at: http://www.statistics.gov.uk/cci/article.asp?id=2408

Everett G (2011). 'Content of Blue Book 2011', Economic and Labour Market Review, April 2011, Volume 5, No 4, pp 87-85. Available at: http://www.statistics.gov.uk/articles/elmr/elmr-apr11everett.pdf

Hughes J, James G, Evans A and Prestwood D (2009). 'Implementation of Standard Industrial Classification 2007: December 2009 update', Economic and Labour Market Review, December 2009, Volume 3, No 12, pp 51-55. Available at: http://www.statistics.gov.uk/cci/article.asp?id=2341

Jenkins C, Jones T and Pegler K (2010). Developments in Services Producer Price Indices, Nonjournal article, ONS.

Available at: $\underline{\text { http://www.statistics.gov.uk/CCl/article.asp?ID }=2394}$

Jenkins C and Papa A (2011). The Development of Price Indices for Professional Business Services and Cargo Handling, Non-journal article, ONS. Available at:

http://www.statistics.gov.uk/CCl/article.asp?ID=2695

McLaren C (2009). Information paper: Changes to the Retail Sales methodology, Non-journal article, ONS.

Available at: $\underline{\text { http://www.statistics.gov.uk/cci/article.asp?ID=2186 }}$

Office for National Statistics (2002). UK Price and Volume (ESA95) Inventory. Available at: http://www.statistics.gov.uk/downloads/theme economy/PVInventory.pdf

Office for National Statistics (2003). The New Inflation Target: The Statistical Perspective.

Available at: http://www.statistics.gov.uk/statbase/product.asp?vlnk=10913

Office for National Statistics (2007). Statistics on Trade in Goods, National Statistics Methodological Series No. 36.

Available at: http://www.statistics.gov.uk/downloads/theme other/FinalGSSMethodspaper.pdf

Office for National Statistics (2010a). Consumer Price Indices Technical Manual. 2010 Edition. Available at: http://www.statistics.gov.uk/statbase/product.asp?vlnk=2328

Office for National Statistics (2010b). Producer Prices October 2010 Statistical Bulletin, Available at: http://www.statistics.gov.uk/pdfdir/ppi1110.pdf 
Office for National Statistics (2010c). GDP(O) Source Data consistent with Blue Book 2010, Available at: http://www.ons.gov.uk/about-statistics/user-guidance/ios-methodology/sourcedata/index.html

Pike R and Drew S (2002). 'Experimental Monthly Index of Services', Economic Trends, No. 583, June 2002

Available at: www.statistics.gov.uk/articles/economic trends/ET June02 Rob Pike.pdf

Walton A, Youll R and Hunt C (2008). Impact of methodological changes to the Index of Production, Non-journal article, ONS.

Available at: http://www.statistics.gov.uk/cci/article.asp?id=2015 


\section{Annex A: Further detail on the systematic change in deflation methodology}

The move to improve the consistency of deflators implicitly means that there will be changes to deflator methods across the board. This annex discusses:

- Recent changes to the classification used for EPI and IPI

- Changes to the major output and expenditure components of GDP

\section{Changes to EPI and IPI}

The UK has historically collected and published import and export price series according to trade classifications of goods and services. The IPI was collected and published on a Standard International Trade Classification (SITC) basis and the EPI according to the Combined Nomenclature (CN). However, in November 2010, the UK began to publish all producer prices according to the CPA 2008 (see ONS, 2010b for more information). This brings the EPI and IPI classification in line with the other producer price series as well as meeting the core requirements of National Accounts.

\section{GDP(O), Index of Production and Index of Services}

Excluding changes to use CPI series, the source of deflators remains largely the same within the short-term output systems. However, the method with which deflators are applied will change. At present, the output of each industry is deflated by an industry deflator. For the industries covered by the Index of Production (mining and quarrying, manufacturing and utilities) an industry deflator is derived by weighting together the main products supplied by that industry. For these industries the main 20 products are used for each industry - this is explained in more detail in Walton et al. (2008). For services most industries are deflated by the main product. Whilst most industries supply products other than their dominant product, this approach assumes that the price movements of these products move in the same way.

Under the new system, product deflators are weighted together for each industry using the balanced product breakdown from the Supply and Use Tables. This improved method will ensure that the resultant industry deflator reflects all the products produced by that industry. 


\section{Gross Fixed Capital Formation}

In the current GFCF system, capital expenditure is deflated by industry and uses deflators that weight together the producer prices by product. As capital items can either be produced domestically or imported, the price series are a combination of PPI and IPI series.

In the new system, deflation will take place on a product basis using the product deflators from the GDP(O) system. However, for the capital goods that are imported, IPI series will also be used. As with the current system, the effective industry deflators are combined using weights that reflect the capital expenditure for that industry. For services, as import prices are not available, the GDP(O) product deflators are used on their own.

\section{Changes in inventories}

As with GFCF, changes in inventories will also use the GDP(O) deflators to deflate on a product basis. The full details of the deflators currently used by industry and type of inventory can be found in the Price and Volume Inventory (ONS, 2002). This will mean that the widespread use of RPI series for the other industries will be improved with more specific deflators.

\section{Trade in Goods}

The outputs of the Trade in Goods system are published on two separate classifications. The SITC classification is the focus of the main release but the system also produces data on a CPA basis for the main national accounts. The underlying current price data is collected by HMRC at the 8digit level. The current approach is to trim the classification to the 6-digit level and deflate the series using detailed EPI and IPI series which are classified to the trade classifications.

The new system uses the concept of building blocks. Essentially, in order to meet the dual-coded requirements of the system, building blocks have been created which intersect the 3-digit CPA level and the 2-digit SITC level. It is at this level where deflation occurs, and the data are then aggregated up the different product hierarchies.

As with the current approach, coverage is not complete for either the IPI or EPI series. National Accounts have historically developed standard methods in order to fill the gaps. This is explained in full in ONS (2007), and the same principles have been applied to the new set of deflators. 


\section{Trade in Services}

Throughout the Index of Services development programme (Pike \& Drew, 2002) deflation methods were harmonised with Trade in Services wherever practicable. The current system uses a mixture of:

- RPI series

- weight modified and exchange rate adjusted CPI series (denominated in foreign currency) (WMCPI)

- productivity adjusted AWE series

- external price series (such as sea freight indices)

- deflators from other National Accounts systems

At Blue Book 2011, Trade in Services will use deflators from GDP(O) and HHFCE wherever relevant, but will still use a number of specific deflators where necessary. Table A1 illustrates deflator usage by exports and imports from Blue Book 2011.

\section{Table A1 Deflator usage in Trade in Services from Blue Book 2011}

\begin{tabular}{cllc}
\hline Trade Direction & & Deflator & $\%$ \\
\hline Exports & Trade in Services deflators & $46 \%$ \\
& GDP(O) deflators & $39 \%$ \\
& HHFCE deflators & $14 \%$ \\
\multirow{2}{*}{ Imports } & Trade in Services deflators & $82 \%$ \\
& GDP(O) deflators & $18 \%$ \\
\hline
\end{tabular}

\section{Other systems}

For Non-Profit Institutions Serving Households (NPISHs), all deflators will be picked up from GDP(O) from Blue Book 2011. For General Government Final Consumption Expenditure (GGFCE), most deflators used in GGFCE will be picked up from the GDP(O) system. For HHFCE, there are no further changes beyond the move to use CPI series. 


\section{Annex B: Further detail on the change to deflators based on the CPI rather than the RPI}

Currently, the RPI is used most significantly as part of GDP(O) and HHFCE. In this section we will focus on these two systems in order to understand current usage and set-out the changes which will be introduced. Table B1 shows which other National Accounts outputs will also be affected as a consequence. Note that many of these systems will pick up GDP(O) deflators from Blue Book 2011, rather than simply replace their RPI series with CPI. This is covered in Annex A of this article.

\section{Table B1 RPI usage by National Accounts Components}

\begin{tabular}{|c|c|c|c|}
\hline NA Component & RPI used \% & $\%$ of GDP & Details \\
\hline $\operatorname{GDP}(\mathrm{O})$ & $18 \%$ & $100 \%$ & Full details provided in this article \\
\hline HHFCE & $65 \%$ & $62 \%$ & Full details provided in this article \\
\hline NPISH & $40 \%$ & $2 \%$ & $\begin{array}{l}\text { The RPI excluding mortgage interest payments (RPIX) used generally, } \\
\text { apart from education and capital consumption }\end{array}$ \\
\hline GGFCE & $7 \%$ & $22 \%$ & $\begin{array}{l}\text { Around four-fifths of output is estimated using direct (activity- or labour- } \\
\text { based) measures for which no deflation is required. The remainder is } \\
\text { estimated indirectly by deflating expenditure, within which procurement is } \\
\text { deflated using a mix of RPI/RPIX and PPI indices. Currently, around four } \\
\text { per cent of GGFCE relates to Central Government expenditure that is } \\
\text { deflated using RPIX and three per cent to Local Government. }\end{array}$ \\
\hline Trade in Services & $18 \%{ }^{*}$ & $\mathrm{n} / \mathrm{a}$ & $\begin{array}{l}\text { Used for approximately } 18 \text { per cent of export services and not used for } \\
\text { imports (based on } 2009 \text { data from the } 2010 \text { Pink Book). Three main areas } \\
\text { of services use RPI: } \\
\text { - Transportation services (RPI excluding housing) } \\
\text { - Travel (Detailed RPI series weighted by expenditure by visitors to the } \\
\text { UK) } \\
\text { - Royalties and license fees (RPI excluding housing) }\end{array}$ \\
\hline Changes in inventories & $55 \%$ & $\mathrm{n} / \mathrm{a}$ & $\begin{array}{l}\text { Used to deflate retail, part of motor trades and other industries. As a } \\
\text { proportion of the total level of inventories, these industries accounted for } \\
55 \text { per cent at the end of } 2009 \text {. } \\
\text { - } \quad \text { Retail - detailed RPI series weighted by sales } \\
\text { - Motor trades - RPI for motor vehicles } \\
\text { - Other industries - RPI }\end{array}$ \\
\hline $\begin{array}{l}\text { Gross Fixed Capital } \\
\text { Formation }\end{array}$ & $2 \%$ & $17 \%$ & Only used in a very limited way to deflate artistic originals \\
\hline
\end{tabular}

* Applicable to exports of services only

Please see the UK Price and Volume (ESA95) Inventory (ONS, 2002), for more information.

GDP percentages relate to the 2008 current price levels as published in Blue Book 2010 (Table 1.2). Note that some aggregates are net figures, so a percentage has not been provided.

Unless noted RPI usage percentages come from the Price and Volume Inventory Annexes 


\section{GDP(O)}

GDP(O) compiles short-term volume estimates of Gross Value Added (GVA) using output based measures. Typically, the monthly turnover data for an industry is deflated by an industry deflator that reflects the predominant products produced by that industry. In this respect, RPI series are used in three main ways as a deflator within $\operatorname{GDP}(\mathrm{O})$ :

- detailed RPI price series are used to deflate industry output where the goods and services produced are consumed in some proportion by households

- RPI excluding mortgage interest payments and indirect taxes (RPIY) is used to deflate industry output where no specific prices series are available - it is usual practice in the UK to combine RPIY equally with the relevant AWE series

- RPI series are also implicitly used where GDP(O) uses data from HHFCE

Table B2 provides the breakdown of deflators usage by GVA weight in GDP(O).

\section{Table B2 Breakdown of deflator usage in GDP(O)}

\begin{tabular}{|c|c|}
\hline Consumer price used & GVA share \\
\hline Top level RPIY series & $5.4 \%$ \\
\hline Low-level RPI series & $10.5 \%$ \\
\hline RPI series used via HHFCE & $2.5 \%$ \\
\hline Total proportion of GDP(O) which just uses RPI & $18.4 \%$ \\
\hline $\mathrm{CPI}$ series via $\mathrm{RSI}$ & $5.4 \%$ \\
\hline Low-level CPI series & $0.3 \%$ \\
\hline Total proportion of GDP(O) which just uses $\mathrm{CPI}$ & $5.7 \%$ \\
\hline Total proportion of GDP(O) which uses consumer prices (either RPI or CPI) & $24.0 \%$ \\
\hline Producer Price Indices (covering PPI, EPI and IPI) & $21.7 \%$ \\
\hline Services Producer Price Indices & $9.7 \%$ \\
\hline Average Weekly Earnings & $7.4 \%$ \\
\hline Other deflators (Agriculture Price Index, FTSE, Department for Business Innovation \& Skills series) & $13.6 \%$ \\
\hline Direct volume measures & $23.6 \%$ \\
\hline Total & $100 \%$ \\
\hline
\end{tabular}

These proportions are based on Blue Book 2010 GVA weights for 2006. Sub-totals and totals in italics.

Overall, almost a quarter of $\operatorname{GDP}(\mathrm{O})$ is deflated using a consumer price in some shape or form. Full details of the deflators used in $\operatorname{GDP}(O)$ can be found on the ONS website (see ONS, 2010c). We will now look at each of the five scenarios given at Table B2 in turn. 


\section{CPIY replacing the use of RPIY}

Whilst the coverage of producer prices in the manufacturing sector is comprehensive and well established, the collection and publishing of SPPI series is a relatively recent development. As a result, the UK is in an ongoing process of developing the SPPI across the service sector (see Jenkins et al, 2010 for more details). To date 32 series are published on a regular basis, with five new series published on an experimental basis in June 2011 (Jenkins \& Papa, 2011), but this still leaves a number of significant services with no specific or appropriate deflator to use.

Since National Accounts need a deflator for each product, alternative approaches are required. As part of the development of the Index of Services in the early 2000s, the deflation methods for the service sector were thoroughly reviewed and the approach of combining RPIY equally with the Section level AWE (adjusted for productivity) was ratified. This method assumes that output prices for service sector products are driven by labour costs and other general changes in goods and services. Typically, this combined deflator is used where there is no, or very little, business to consumer activity. For Blue Book 2011, we will be replacing the RPIY element with the CPI excluding the effects of indirect taxation (CPIY).

\section{Replacement of low-level RPI series}

The most common use of RPI series is where specific price indices are used to deflate output. Where possible, RPI series at the published level are used, but when that is not possible, lower level series or combinations of lower level series are used. Examples are provided in Table B3.

\section{Table B3 Examples of current RPI usage in GDP(O)}

\begin{tabular}{lcll}
\hline \multicolumn{1}{c}{ Type } & CPA & Description & Current deflator \\
\hline Top-level RPIY series & 74.11 & Legal activities & $\begin{array}{l}\text { RPIY weighted equally with AWE for Section K } \\
\text { adjusted for changes in productivity }\end{array}$ \\
Low-level RPI series & 63.30 & $\begin{array}{l}\text { Activities of travel agencies and } \\
\text { tour operators }\end{array}$ & RPI for UK and foreign holidays \\
RPI series via HHFCE & $92.6 / 92.72$ & Sporting and recreational activities HHFCE implied deflator for Recreational and Sporting \\
& & & Activities \\
\hline
\end{tabular}

In updating these series to CPI, there is a basic issue that the classification systems used by RPI and $\mathrm{CPI}$ are different. CPI uses a standard international classification system that is consistent with the system used in the National Accounts - Classification of Individual Consumption by Purpose (COICOP), whereas the RPI uses a bespoke UK specific classification. In replacing the current series with CPI, published level CPI series were used wherever possible, but for ten products, bespoke series have been compiled. This is where a published COICOP series is not specific enough for the product in question, and the underlying data are robust enough to support lower level indices. Examples for each are given in Tables B4 and B5. 


\section{Table B4 Examples of how RPI series will be replaced by CPI series}

This table shows, for comparable products between CPA 2002 and CPA 2008 (the current and new product classifications), the RPI series that are currently being used and the replacement CPI series.

\begin{tabular}{|c|c|c|}
\hline Description & CPA Codes & Deflator \\
\hline \multirow[t]{2}{*}{ Restaurant and mobile food serving services } & CPA 2002: 55.3 & $\begin{array}{l}\text { RPI: Weighted mean of: } \\
\text { 1. RPI: Licensed restaurants } \\
\text { 2. RPI: Unlicensed restaurants \& cafes } \\
\text { 3. RPI: Takeaway food shops }\end{array}$ \\
\hline & CPA 2008: 56.1 & CPI: 11.1.1 - Restaurants, cafes etc \\
\hline \multirow[t]{2}{*}{ Sea and coastal passenger water transport } & CPA 2002: 66.10/1 & RPI: Sea fares \\
\hline & CPA 2008: 50.11 & CPI: 07.3.4 - Sea and inland waterways \\
\hline \multirow[t]{2}{*}{ Creative, arts and entertainment services } & CPA 2002: 92.31 & RPI: Entertainment and other \\
\hline & CPA 2008: 90 & $\begin{array}{l}\text { CPI: } 09.4 \text { - Recreational and cultural } \\
\text { services }\end{array}$ \\
\hline \multirow{2}{*}{$\begin{array}{l}\text { Hairdressing and other beauty treatment } \\
\text { services }\end{array}$} & CPA 2002: 93.03 & RPI: Hairdressing \\
\hline & CPA 2008: 96.03 & $\begin{array}{l}\mathrm{CPI}: 12.1 .1 \text { - Hairdressing salons and } \\
\text { personal grooming establishments }\end{array}$ \\
\hline
\end{tabular}

Where the COICOP classification is too general for the product being deflated in CPA, bespoke $\mathrm{CPI}$ series have been constructed by extracting items out of the COICOP group for National Accounts. These bespoke CPI series are listed below.

\section{Table B5 Bespoke CPI series}

\begin{tabular}{|c|c|c|}
\hline CPA Code & COICOP Code & Details \\
\hline 49.1 & CPI for 07.3.1 & Excluding London Transport \& other underground/Metro fares only \\
\hline 49.31 & $\begin{array}{l}\text { CPI for } 07.3 .1 \\
\text { CPI for } 07.3 .2\end{array}$ & $\begin{array}{l}\text { London Transport \& other underground/Metro fares only \& } \\
\text { Excluding house removals and taxi and minicab fares }\end{array}$ \\
\hline 49.32 & CPI for 07.3 .2 & Taxi and minicab fares only \\
\hline 52.21-3.CPI & CPI for 07.2 .4 & Car park charges only \\
\hline $55.2-9$ & CPI for 09.6 & UK holidays only \\
\hline 59.CPI & CPI for 09.4 .2 & Cinema admission only \\
\hline 77.1 & CPI for 07.2 .4 & Car and van hire only \\
\hline 77.2 & CPI for 09.4 .2 & DVD rental and TV rental only \\
\hline 85.5.CPI & CPI for 07.2 .4 & Driving school lesson only \\
\hline 96.03 & CPI for 12.7 & Basic funeral cremation only \\
\hline
\end{tabular}

Users should also note that there are two cases where GDP(O) will continue to use RPI series. These are for estate agent fees and trade union subscriptions. This is due to the CPI not covering these products at present. 


\section{RPI series via HHFCE}

For industries such as rental on dwellings, recreational services and services provided to households, the most appropriate source for measuring output comes from HHFCE. Given that the switch to $\mathrm{CPI}$ covers all of the accounts, GDP(O) will implicitly pick up these CPI series from HHFCE.

\section{CPI series via Retail Sales Index}

Similar to the HHFCE indicators, the output for the retail industry is taken from the RSI. As explained earlier, RSI introduced CPI series in May 2009 and implicitly these were then used in $\operatorname{GDP}(\mathrm{O})$. Therefore, the more general update will have no impact for the measurement of retail output.

\section{Purchasers' price versus basic price}

For GDP(O), users may note that a price index valued at purchasers' prices is used to deflate a basic price National Accounts concept. National Accounts should adjust the purchasers' price index to take account of changes in trade and transport margins as well as changes in the rates of taxes and subsidies on products. Therefore, in these circumstances, GDP(O) uses prices valued at purchasers' prices as a proxy for the basic price. Within the GDP(O) system a specific adjustment is used to correct consumer prices and has been used to adjust out the effects of the recent VAT changes. The adjustments are made using intelligence from the Consumer Prices team. For further information on this issue please see Eurostat (2001, chapter 3.1.1.1).

\section{Household Final Consumption Expenditure}

Compared with $\operatorname{GDP}(\mathrm{O})$, the changes which will be introduced at Blue Book 2011 are more straightforward. As HHFCE uses the COICOP classification, it is not affected by the changes to the SIC and CPA classifications.

In the current system, HHFCE estimates are compiled from 256 low-level series. It is at this level where deflation currently takes place and therefore requires detailed deflators. At present the HHFCE system uses detailed item level price series from the RPI. Under the new system design, deflation will use CPI series at the published 4-digit COICOP level. Whilst more detailed price deflators are conceptually preferable, the decision to deflate at the 4-digit level is based on the grounds of data quality. An example of this change can be seen in Table B6. 


\section{Table B6 Example of change to deflation for HHFCE}

As an example of the change to using CPI deflators, this table shows the current breakdown of the first COICOP group 01.1.1 - Bread and cereals.

\begin{tabular}{|c|c|c|c|}
\hline \multicolumn{2}{|r|}{ Current breakdown of 01.1.1 } & \multicolumn{2}{|r|}{ Breakdown of 01.1.1 from Blue Book 2011} \\
\hline COICOP & Description & COICOP & Description \\
\hline 01.1 .1 & Bread and cereals & 01.1 .1 & Bread and cereals \\
\hline $01.1 .1 \mathrm{~N} 1$ & Rice & 01.1.1N1 & Bread, cakes \& non-chocolate biscuits \\
\hline $01.1 .1 \mathrm{~N} 2$ & Bread and non-chocolate biscuits & $01.1 .1 \mathrm{~N} 2$ & Chocolate biscuits \\
\hline $01.1 .1 \mathrm{~N} 3$ & Chocolate biscuits & $01.1 .1 \mathrm{~N} 3$ & Cereals \& cereal products \\
\hline $01.1 .1 \mathrm{~N} 4$ & Pasta products & & \\
\hline $01.1 .1 \mathrm{~N} 5$ & Pastry-cook products & & \\
\hline $01.1 .1 \mathrm{~N} 6$ & Cereals & & \\
\hline $01.1 .1 \mathrm{~N} 7$ & Cereal products & & \\
\hline \multicolumn{2}{|c|}{$\begin{array}{l}\text { Deflation is currently done at the lower level with individual } \\
\text { RPI series for each product }\end{array}$} & \multicolumn{2}{|c|}{ Deflation will be done at the 01.1.1 level using the CPI for 01.1.1 } \\
\hline
\end{tabular}

The full breakdown of deflators currently used in HHFCE can be found in the UK Price and Volume Inventory (ONS, 2002). Where applicable, published level RPI series are used to deflate products. However, more commonly, lower level item indices are weighted together to provide composite indices that match the level required for COICOP deflation. The weights used in this index construction are the corresponding HHFCE estimates for the previous calendar year. The approach to deflation can be approximated to taking the CPI components and weights and using an arithmetic mean to calculate aggregate price series instead of using a geometric mean.

The two following tables summarise the deflator usage within HHFCE. Table B7 shows the usage at the top-level, and Table B8 the breakdown by the main COICOP categories.

\section{Table B7 Breakdown of current consumer price usage in HHFCE}

\begin{tabular}{|c|c|}
\hline Consumer price used & Expenditure share \\
\hline Item level RPI series - RPI series below published level & $53.4 \%$ \\
\hline Published level RPI series & $11.6 \%$ \\
\hline Total proportion of HHFCE which uses consumer prices & $65.0 \%$ \\
\hline Other deflators or direct volume & $35.0 \%$ \\
\hline
\end{tabular}

These proportions are based on Blue Book 2010 current price estimates for 2008. 


\section{Table B8 HHFCE current deflation method by COICOP group}

\begin{tabular}{|c|c|c|c|}
\hline COICOP Code & Description & $\begin{array}{l}\text { Consumer Price } \\
\text { Deflator \% }\end{array}$ & Deflation methods \\
\hline 01 & Food and non-alcoholic beverages & $100 \%$ & Item level RPI series \\
\hline 02 & Alcoholic beverages and tobacco & $43 \%$ & Published level RPI series and direct volume series \\
\hline 03 & Clothing and footwear & $100 \%$ & Item level RPI series and published level RPI series \\
\hline 04 & $\begin{array}{l}\text { Housing, water, electricity, gas and other } \\
\text { fuels }\end{array}$ & $30 \%$ & $\begin{array}{l}\text { Item level RPI series, published level RPI series and } \\
\text { direct volume series }\end{array}$ \\
\hline 05 & Furnishings and household goods & $100 \%$ & Item level RPI series \\
\hline 06 & Health & $73 \%$ & $\begin{array}{l}\text { Item level RPI series, direct volume series and other } \\
\text { deflators }\end{array}$ \\
\hline 07 & Transport & $51 \%$ & $\begin{array}{l}\text { Item level RPI series, direct volume series and other } \\
\text { deflators }\end{array}$ \\
\hline 08 & Communication & $100 \%$ & Item level RPI series \\
\hline 09 & Recreation and culture & $100 \%$ & Item level RPI series and published level RPI series \\
\hline 10 & Education & $100 \%$ & Published level RPI series \\
\hline 11 & Restaurants and hotels & $66 \%$ & $\begin{array}{l}\text { Item level RPI series, direct volume series and other } \\
\text { deflators }\end{array}$ \\
\hline 12 & Miscellaneous goods and services & $49 \%$ & $\begin{array}{l}\text { Item level RPI series, published level RPI series, } \\
\text { direct volume series and other deflators }\end{array}$ \\
\hline
\end{tabular}

These proportions are based on Blue Book 2010 current price estimates for 2008. 


\section{Annex C: The "formula effect"}

A geometric mean is mainly used in the CPI (for around 70 per cent of the index) to combine individual prices at the first stage of aggregation whereas the RPI uses arithmetic means. As a general mathematical result, the geometric mean of a given set of values is always lower than that of an arithmetic mean that is based on the average of price relatives (AR) approach, except when those values are all equal (there is then no difference). An estimate based on the ratio of averages (RA) form of the arithmetic mean can, though, be lower than one based on the geometric mean. $A R$ and RA are both used in the RPI whereas where a geometric mean is not used in the CPI, only the RA approach is used.

The scale of the difference of the results produced using the geometric mean and arithmetic mean approaches depends on the dispersion of the price relatives (i.e. the ratio of the current period and base period prices); as the variance of the price relatives increases, so does the difference between the geometric mean and arithmetic mean results.

A breakdown of the differences between the CPI and RPI, including the impact of the formula effect, is provided each month in Table 4 in the consumer price indices statistical bulletin. The latest data can be found on the ONS website.

\section{Box Illustration of formula effect}

Denoting the arithmetic and geometric mean functions as $a(x)$ and $g(x)$ respectively, in the case of 2 values, $x_{1}$ and $x_{2}$, the functions are defined as follows:

$$
\begin{aligned}
& a(x)=\left(x_{1}+x_{2}\right) / 2 \\
& g(x)=\sqrt{ }\left(x_{1} \cdot x_{2}\right) \\
& \text { so } a(x)=\left(\sqrt{ } x_{1}{ }^{2}+\sqrt{ } x_{2}{ }^{2}+2 \sqrt{ }\left(x_{1} \cdot x_{2}\right)-2 \sqrt{ }\left(x_{1} \cdot x_{2}\right)\right) / 2 \\
& \quad a(x)=g(x)+\left(\sqrt{ } x_{1}-\sqrt{ } x_{2}\right)^{2} / 2
\end{aligned}
$$

Since the final term on the right-hand side is always greater than or equal to zero, it follows that the arithmetic mean of two values is always greater than the geometric mean except where the two values are equal.

Source: The New Inflation Target: the Statistical Perspective. ONS (2003) 


\section{Annex D: National Accounts classification of industries and products under SIC 2007 and CPA 2008}

Under SIC 2007, it has been agreed to compile the National Accounts by reference to annual Supply and Use Tables identifying 114 industries and 114 products. However two of these groupings are outside the UK production boundary and are not normally included in the presentation of the UK National Accounts. Therefore, whilst there are 114 industries and products defined in the classification, only 112 are actually included in the UK National Accounts.

This new breakdown includes an expansion in the level of detail in the service sector. Users should note that this level will be applied consistently across nearly all National Accounts outputs. The following table relates to the industry classification, the product classification is exactly the same except that the description describes the products rather than the activities.

The table also shows how the 114 level relates to the breakdown required under the revised European System of Accounts Transmission Programme, which governs the data requirements for EU Member States. These are the A3, A10, A21, A38 and A64 columns within the table below. More information on the definitions of these levels can be found in European Commission (2010).

\begin{tabular}{|c|c|c|c|c|c|c|}
\hline SIC 2007 Codes & Description & A3 & A10 & A21 & A38 & A64 \\
\hline 01 & Crop and animal production, hunting and related service activities & 1 & 1 & A & A & 1 \\
\hline 02 & Forestry and logging & 1 & 1 & A & A & 2 \\
\hline 03 & Fishing and aquaculture & 1 & 1 & A & A & 3 \\
\hline 05 & Mining of coal and lignite & 2 & 2 & $\mathrm{~B}$ & B & 4 \\
\hline 06 & Extraction of crude petroleum and natural gas & 2 & 2 & B & B & 4 \\
\hline 07 & Mining of metal ores & 2 & 2 & $\mathrm{~B}$ & B & 4 \\
\hline 08 & Other mining and quarrying & 2 & 2 & $\mathrm{~B}$ & B & 4 \\
\hline 09 & Mining support service activities & 2 & 2 & $\mathrm{~B}$ & B & 4 \\
\hline 10.1 & Processing and preserving of meat and production of meat products & 2 & 2 & C & $\mathrm{CA}$ & 5 \\
\hline $10.2-3$ & $\begin{array}{l}\text { Processing and preserving of fish, crustaceans, molluscs, fruit and } \\
\text { vegetables }\end{array}$ & 2 & 2 & C & $\mathrm{CA}$ & 5 \\
\hline 10.4 & Vegetable and animal oils and fats & 2 & 2 & $\mathrm{C}$ & $\mathrm{CA}$ & 5 \\
\hline 10.5 & Dairy products & 2 & 2 & C & $\mathrm{CA}$ & 5 \\
\hline 10.6 & Grain mill products, starches and starch products & 2 & 2 & $\mathrm{C}$ & $\mathrm{CA}$ & 5 \\
\hline 10.7 & Bakery and farinaceous products & 2 & 2 & C & $\mathrm{CA}$ & 5 \\
\hline 10.8 & Other food products & 2 & 2 & C & $\mathrm{CA}$ & 5 \\
\hline 10.9 & Prepared animal feeds & 2 & 2 & $\mathrm{C}$ & $\mathrm{CA}$ & 5 \\
\hline $11.01-6$ & Alcoholic beverages & 2 & 2 & $\mathrm{C}$ & $\mathrm{CA}$ & 5 \\
\hline 11.07 & Soft drinks; production of mineral waters and other bottled waters & 2 & 2 & C & $\mathrm{CA}$ & 5 \\
\hline 12 & Tobacco products & 2 & 2 & C & $\mathrm{CA}$ & 5 \\
\hline 13 & Textiles & 2 & 2 & C & $\mathrm{CB}$ & 6 \\
\hline 14 & Wearing apparel & 2 & 2 & $\mathrm{C}$ & $\mathrm{CB}$ & 6 \\
\hline
\end{tabular}




\begin{tabular}{|c|c|c|c|c|c|c|}
\hline SIC 2007 Codes & Description & A3 & A10 & A21 & A38 & A64 \\
\hline 15 & Leather and related products & 2 & 2 & C & $\mathrm{CB}$ & 6 \\
\hline 16 & $\begin{array}{l}\text { Wood and products of wood and cork, except furniture; Articles of } \\
\text { straw and plaiting materials }\end{array}$ & 2 & 2 & $\mathrm{C}$ & $\mathrm{CC}$ & 7 \\
\hline 17 & Paper and paper products & 2 & 2 & C & $\mathrm{CC}$ & 8 \\
\hline 18 & Printing and reproduction of recorded media & 2 & 2 & $\mathrm{C}$ & $\mathrm{CC}$ & 9 \\
\hline 19 & Coke and refined petroleum products & 2 & 2 & C & $C D$ & 10 \\
\hline $20 \mathrm{~A}$ & $\begin{array}{l}\text { Industrial gases, inorganics and fertilisers (all inorganic chemicals) - } \\
20.11 / 13 / 15\end{array}$ & 2 & 2 & $\mathrm{C}$ & CE & 11 \\
\hline $20 \mathrm{~B}$ & Petrochemicals - 20.14/16/17/60 & 2 & 2 & $\mathrm{C}$ & CE & 11 \\
\hline $20 \mathrm{C}$ & Dyestuffs, agro-chemicals - 20.12/20 & 2 & 2 & C & CE & 11 \\
\hline 20.3 & Paints, varnishes and similar coatings, printing ink and mastics & 2 & 2 & C & CE & 11 \\
\hline 20.4 & $\begin{array}{l}\text { Soap and detergents, cleaning and polishing preparations, perfumes } \\
\text { and toilet preparations }\end{array}$ & 2 & 2 & $\mathrm{C}$ & CE & 11 \\
\hline 20.5 & Other chemical products & 2 & 2 & C & CE & 11 \\
\hline 21 & Basic pharmaceutical products and pharmaceutical preparations & 2 & 2 & C & $\mathrm{CF}$ & 12 \\
\hline 22 & Rubber and plastic products & 2 & 2 & $\mathrm{C}$ & CG & 13 \\
\hline 23OTHER & Glass, refractory, clay, porcelain, ceramic, stone products - 23.1-4/7-9 & 2 & 2 & C & CG & 14 \\
\hline $23.5-6$ & Cement, lime, plaster and articles of concrete, cement and plaster & 2 & 2 & $\mathrm{C}$ & CG & 14 \\
\hline $24.1-3$ & Basic iron and steel & 2 & 2 & C & $\mathrm{CH}$ & 14 \\
\hline $24.4-5$ & Other basic metals and casting & 2 & 2 & C & $\mathrm{CH}$ & 15 \\
\hline 25OTHER & $\begin{array}{l}\text { Fabricated metal products, excluding weapons and ammunition } \\
-25.1-3 / 5-9\end{array}$ & 2 & 2 & C & $\mathrm{CH}$ & 16 \\
\hline 25.4 & Weapons and ammunition & 2 & 2 & $\mathrm{C}$ & $\mathrm{CH}$ & 16 \\
\hline 26 & Computer, electronic and optical products & 2 & 2 & C & $\mathrm{Cl}$ & 17 \\
\hline 27 & Electrical equipment & 2 & 2 & C & CJ & 18 \\
\hline 28 & Machinery and equipment n.e.c. & 2 & 2 & C & CK & 19 \\
\hline 29 & Motor vehicles, trailers and semi-trailers & 2 & 2 & C & $\mathrm{CL}$ & 20 \\
\hline 30.1 & Building of ships and boats & 2 & 2 & C & $\mathrm{CL}$ & 21 \\
\hline 30.3 & Air and spacecraft and related machinery & 2 & 2 & C & $\mathrm{CL}$ & 21 \\
\hline 30OTHER & Other transport equipment - 30.2/4/9 & 2 & 2 & C & $\mathrm{CL}$ & 21 \\
\hline 31 & Furniture & 2 & 2 & C & $\mathrm{CM}$ & 22 \\
\hline 32 & Other manufacturing & 2 & 2 & C & $\mathrm{CM}$ & 22 \\
\hline 33.15 & Repair and maintenance of ships and boats & 2 & 2 & C & $\mathrm{CM}$ & 23 \\
\hline 33.16 & Repair and maintenance of aircraft and spacecraft & 2 & 2 & C & $\mathrm{CM}$ & 23 \\
\hline 33OTHER & Rest of repair; Installation - 33.11-14/17/19/20 & 2 & 2 & C & $\mathrm{CM}$ & 23 \\
\hline 35.1 & Electric power generation, transmission and distribution & 2 & 2 & $\mathrm{D}$ & $\mathrm{D}$ & 24 \\
\hline $35.2-3$ & $\begin{array}{l}\text { Gas; distribution of gaseous fuels through mains; Steam and air } \\
\text { conditioning supply }\end{array}$ & 2 & 2 & $\mathrm{D}$ & $\mathrm{D}$ & 24 \\
\hline 36 & Water collection, treatment and supply & 2 & 2 & $E$ & $E$ & 25 \\
\hline 37 & Sewerage & 2 & 2 & $E$ & E & 26 \\
\hline
\end{tabular}




\begin{tabular}{|c|c|c|c|c|c|c|}
\hline SIC 2007 Codes & Description & A3 & A10 & A21 & A38 & A64 \\
\hline 38 & Waste collection, treatment and disposal activities; materials recovery & 2 & 2 & $\mathrm{E}$ & E & 26 \\
\hline 39 & Remediation activities and other waste management services & 2 & 2 & E & E & 26 \\
\hline 41 & Construction of buildings & 2 & 3 & $\mathrm{~F}$ & $\mathrm{~F}$ & 27 \\
\hline 42 & Civil engineering & 2 & 3 & $\mathrm{~F}$ & $\mathrm{~F}$ & 27 \\
\hline 43 & Specialised construction activities & 2 & 3 & $\mathrm{~F}$ & $\mathrm{~F}$ & 27 \\
\hline 45 & $\begin{array}{l}\text { Wholesale and retail trade and repair of motor vehicles and } \\
\text { motorcycles }\end{array}$ & 3 & 4 & G & G & 28 \\
\hline 46 & Wholesale trade, except of motor vehicles and motorcycles & 3 & 4 & G & G & 29 \\
\hline 47 & Retail trade, except of motor vehicles and motorcycles & 3 & 4 & G & G & 30 \\
\hline $49.1-2$ & Rail transport & 3 & 4 & $\mathrm{H}$ & $\mathrm{H}$ & 31 \\
\hline $49.3-5$ & $\begin{array}{l}\text { Land transport services and transport services via pipelines, excluding } \\
\text { rail transport }\end{array}$ & 3 & 4 & $\mathrm{H}$ & $\mathrm{H}$ & 31 \\
\hline 50 & Water transport & 3 & 4 & $\mathrm{H}$ & $\mathrm{H}$ & 32 \\
\hline 51 & Air transport & 3 & 4 & $\mathrm{H}$ & $\mathrm{H}$ & 33 \\
\hline 52 & Warehousing and support activities for transportation & 3 & 4 & $\mathrm{H}$ & $\mathrm{H}$ & 34 \\
\hline 53 & Postal and courier activities & 3 & 4 & $\mathrm{H}$ & $\mathrm{H}$ & 35 \\
\hline 55 & Accommodation & 3 & 4 & I & 1 & 36 \\
\hline 56 & Food and beverage service activities & 3 & 4 & I & I & 36 \\
\hline 58 & Publishing activities & 3 & 5 & $\mathrm{~J}$ & $\mathrm{JA}$ & 37 \\
\hline 59 & $\begin{array}{l}\text { Motion picture, video and TV programme production, sound recording } \\
\text { and music publishing activities }\end{array}$ & 3 & 5 & $\mathrm{~J}$ & JA & 38 \\
\hline 60 & Programming and broadcasting activities & 3 & 5 & $\mathrm{~J}$ & JA & 38 \\
\hline 61 & Telecommunications & 3 & 5 & $\mathrm{~J}$ & $\mathrm{JB}$ & 39 \\
\hline 62 & Computer programming, consultancy and related activities & 3 & 5 & $\mathrm{~J}$ & $\mathrm{JC}$ & 40 \\
\hline 63 & Information service activities & 3 & 5 & $\mathrm{~J}$ & $\mathrm{JC}$ & 40 \\
\hline 64 & Financial service activities, except insurance and pension funding & 3 & 6 & $\mathrm{~K}$ & $\mathrm{~K}$ & 41 \\
\hline $65.1-2$ & Insurance and reinsurance, except compulsory social security & 3 & 6 & $\mathrm{~K}$ & $\mathrm{~K}$ & 42 \\
\hline 65.3 & Pension funding & 3 & 6 & $\mathrm{~K}$ & $\mathrm{~K}$ & 42 \\
\hline 66 & Activities auxiliary to financial services and insurance activities & 3 & 6 & $\mathrm{~K}$ & $\mathrm{~K}$ & 43 \\
\hline $68.1-2$ & $\begin{array}{l}\text { Buying and selling, renting and operating of own or leased real estate, } \\
\text { excluding imputed rental }\end{array}$ & 3 & 7 & L & L & 44 \\
\hline 68.2IMP & Imputed rental & 3 & 7 & L & L & 44 \\
\hline 68.3 & Real estate activities on a fee or contract basis & 3 & 7 & L & L & 44 \\
\hline 69.1 & Legal activities & 3 & 8 & M & MA & 45 \\
\hline 69.2 & Accounting, bookkeeping and auditing activities; Tax consultancy & 3 & 8 & M & MA & 45 \\
\hline 70 & Activities of head offices; Management consultancy activities & 3 & 8 & M & MA & 45 \\
\hline 71 & Architectural and engineering activities; Technical testing and analysis & 3 & 8 & M & MA & 46 \\
\hline 72 & Scientific research and development & 3 & 8 & M & MB & 47 \\
\hline 73 & Advertising and market research & 3 & 8 & M & $\mathrm{MC}$ & 48 \\
\hline 74 & Other professional, scientific and technical activities & 3 & 8 & M & MC & 49 \\
\hline
\end{tabular}




\begin{tabular}{|c|c|c|c|c|c|c|}
\hline SIC 2007 Codes & Description & A3 & A10 & A21 & A38 & A64 \\
\hline 75 & Veterinary activities & 3 & 8 & M & $\mathrm{MC}$ & 49 \\
\hline 77 & Rental and leasing activities & 3 & 8 & $\mathrm{~N}$ & $\mathrm{~N}$ & 50 \\
\hline 78 & Employment activities & 3 & 8 & $\mathrm{~N}$ & $\mathrm{~N}$ & 51 \\
\hline 79 & $\begin{array}{l}\text { Travel agency, tour operator and other reservation service and related } \\
\text { activities }\end{array}$ & 3 & 8 & $\mathrm{~N}$ & $\mathrm{~N}$ & 52 \\
\hline 80 & Security and investigation activities & 3 & 8 & $\mathrm{~N}$ & $\mathrm{~N}$ & 53 \\
\hline 81 & Services to buildings and landscape activities & 3 & 8 & $\mathrm{~N}$ & $\mathrm{~N}$ & 53 \\
\hline 82 & $\begin{array}{l}\text { Office administrative, office support and other business support } \\
\text { activities }\end{array}$ & 3 & 8 & $\mathrm{~N}$ & $\mathrm{~N}$ & 53 \\
\hline 84 & Public administration and defence; Compulsory social security & 3 & 9 & $\mathrm{O}$ & $\mathrm{O}$ & 54 \\
\hline 85 & Education & 3 & 9 & $P$ & $P$ & 55 \\
\hline 86 & Human health activities & 3 & 9 & Q & QA & 56 \\
\hline 87 & Residential care activities & 3 & 9 & Q & QB & 57 \\
\hline 88 & Social work activities without accommodation & 3 & 9 & Q & QB & 57 \\
\hline 90 & Creative, arts and entertainment activities & 3 & 10 & $\mathrm{R}$ & $\mathrm{R}$ & 58 \\
\hline 91 & Libraries, archives, museums and other cultural activities & 3 & 10 & $\mathrm{R}$ & $\mathrm{R}$ & 58 \\
\hline 92 & Gambling and betting activities & 3 & 10 & $\mathrm{R}$ & $\mathrm{R}$ & 58 \\
\hline 93 & Sports activities and amusement and recreation activities & 3 & 10 & $\mathrm{R}$ & $\mathrm{R}$ & 59 \\
\hline 94 & Activities of membership organisations & 3 & 10 & S & S & 60 \\
\hline 95 & Repair of computers and personal and household goods & 3 & 10 & S & S & 61 \\
\hline 96 & Other personal service activities & 3 & 10 & S & S & 62 \\
\hline 97 & Activities of households as employers of domestic personnel & 3 & 10 & $\mathrm{~T}$ & $\mathrm{~T}$ & 63 \\
\hline $98^{*}$ & $\begin{array}{l}\text { Undifferentiated goods- and services-producing activities of private } \\
\text { households for own use }\end{array}$ & 3 & 10 & $\mathrm{~T}$ & $\mathrm{~T}$ & 63 \\
\hline $99^{*}$ & Activities of extra-territorial organisations and bodies & 3 & 10 & $u$ & $\mathrm{U}$ & 64 \\
\hline
\end{tabular}

* These two groupings lie outside the UK production boundary and are not normally included in the presentation of the UK National Accounts. 